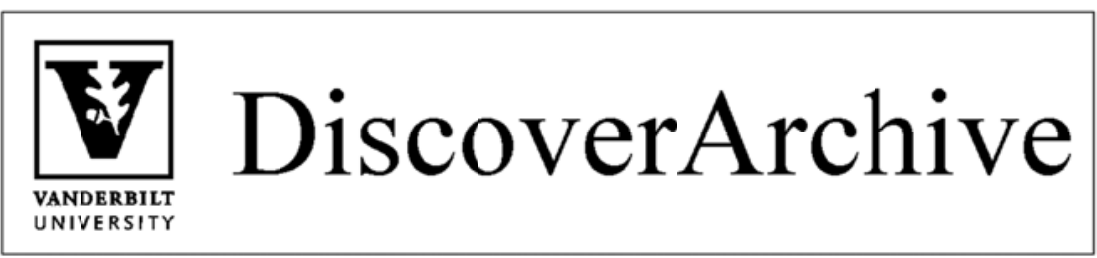

Retrieved from DiscoverArchive,

Vanderbilt University’s Institutional Repository

This work was originally published as W. Kip Viscusi, Does Product Liability Make Us Safer?, in 35 Regulation 242012. 


\title{
Does Product Liability Make Us Safer?
}

\section{Adverse consequences arise from problems with the judicial system and jurors' judgment biases.}

\author{
BY W. KIP VISCUSI Vanderbilt University
}

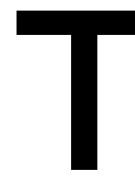
ort liability for personal injuries and property damage caused by products is known as product liability. Among the most prominent products associated with product liability claims are pharmaceuticals, medical devices, private aircraft, automobiles, and cigarettes.

Damages awarded to injured parties raise the costs of providing the product, thus increasing the costs to the firm of selling unsafe products. In theory, where the damages equal the value of the harm, the damages payment leads the firm to internalize the costs of the harm and creates incentives for the firm to produce safer products. In this article I focus primarily on whether American product liability law does in fact enhance product safety.

Posing the question of whether product liability law is safetyenhancing does not, however, imply that this framing of the mission of product liability is appropriate. Higher levels of safety may not be desirable. For almost all products, it does not make economic sense to ensure that products are risk-free. Rather, from the standpoint of economic efficiency, for continuous safety choices the penalties established through tort liability should provide financial incentives for firms to provide the products that achieve a level of risk that equates the incremental benefits of greater safety with the incremental costs. Thus, if the safety level

W. KIP VIscusi is the University Distinguished Professor of Law, Economics, and Management at Vanderbilt University.

This article is taken from the paper "Does Product Liability Make Us Safer?" that Viscusi contributed to the forthcoming book The American Illness, Frank Buckley (ed.), Yale University Press, 2012.

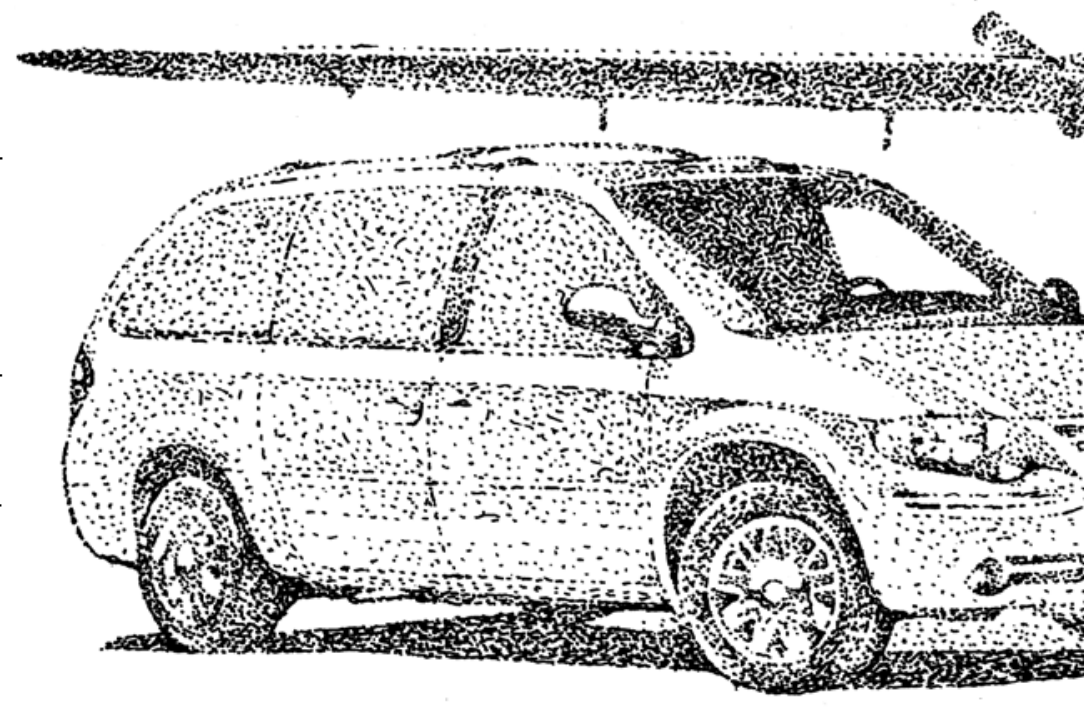

of the product falls short of the efficient level, product liability can potentially play a productive role by penalizing firms for a shortfall between the level of product safety provided and the efficient level of safety, thus pushing the level of safety closer to its efficient level.

This task of establishing efficient incentives for product safety is not limited to a point in time. As technological change evolves over time, firms should continue to improve their products to maintain this benefit-cost balance. Technological change generally will lead to enhanced safety levels in any given product if the changes involve innovations that decrease the costs of providing safer products. If the cost of providing a given level of safety decreases, then the firm will find it efficient to improve 
the safety of the product.

However, technological change also may lead to the introduction of new products posing novel risks. Whether product liability will make products safer is a question that should be framed more broadly in terms of whether product liability also fosters the introduction of welfare-enhancing new products. The court's task of assessing innovative products often entails more problematic judgments than with assessments of existing technologies, so that the concern for safety with respect to innovations may in fact stymie such innovations. Novel products may be safer than existing products but may pose new kinds of risks. If there is a bias of product liability against novel risks, then there will be a disincentive with respect to product innovations.

A review of the empirical evidence and case studies on the role of product liability demonstrates that the idealized world in which the tort liability system is supposed to produce effi-

\section{The Efficient Safety Reference Point}

In a simple economic framework in which firms have constant unit costs of production, providing products with a higher level of safety will result in a higher level of unit costs for the product. In the case of competitive markets, the additional costs associated with safer products will raise unit cost levels, which in turn will raise the price of the product purchased by consumers by an amount equal to the cost of greater safety. Thus consumers are, in effect, purchasing a product liability insurance policy as part of a bundled product. Whether consumer welfare is enhanced by greater safety or whether the additional safety is excessive from consumers' standpoint depends on whether consumers value the safety improvements more than the increased product price.

The role of product liability law in the economy should be

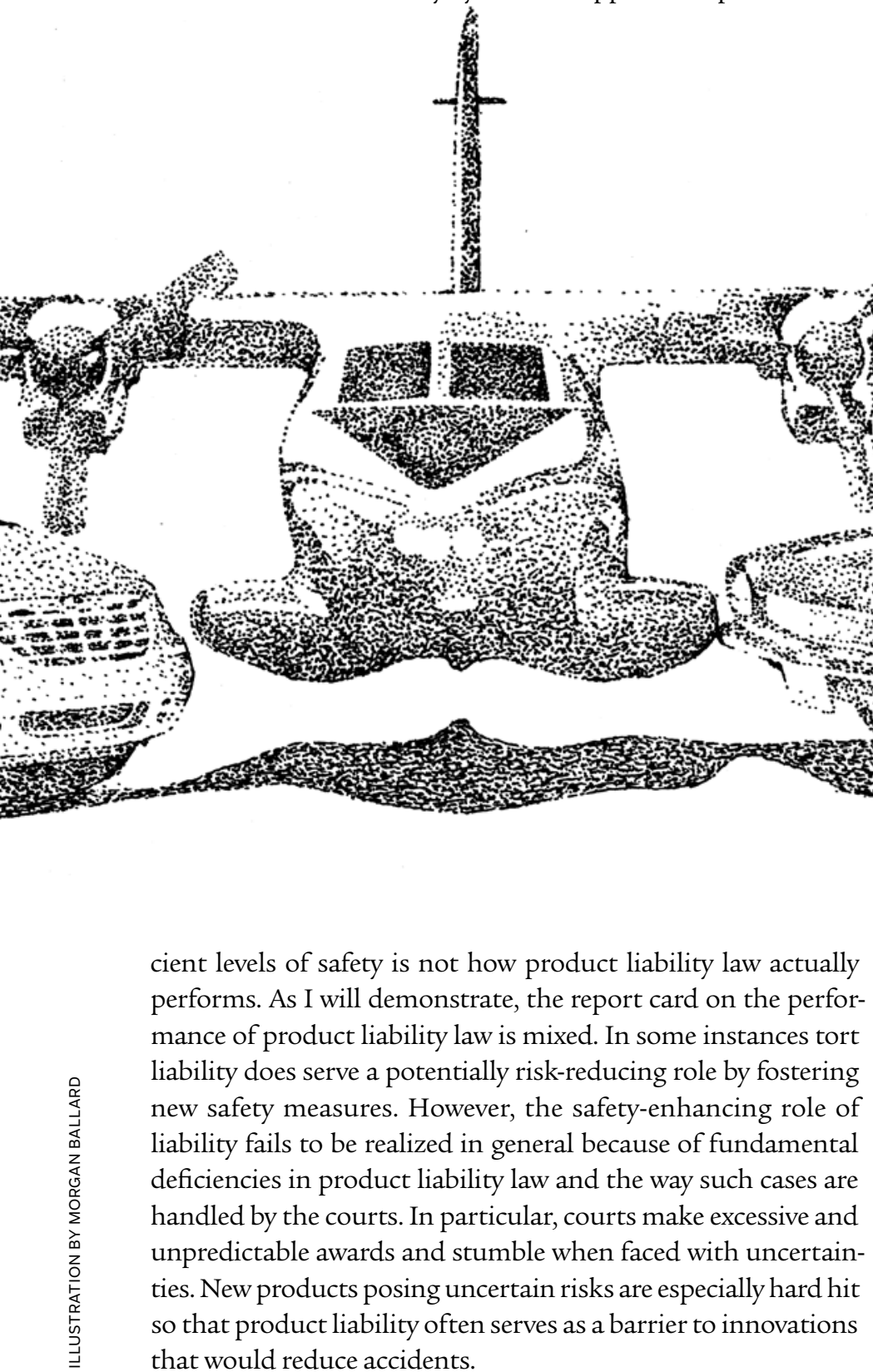

quite selective, since market forces will foster safer products so that safety levels are not generally awry. Indeed, there is no useful function of product liability law if markets function perfectly. In a well-functioning market, firms will deliver products that have an efficient level of safety even in the absence of product liability law. This result assumes that consumers are fully informed of the risks and consequences of their product choices, in which case consumer preferences as expressed in the marketplace will generate the desired mix of products and levels of safety that reflect consumers' valuation of the risk and consequently the associated benefits of safety. If safer products are desirable, consumers will be willing to pay more for these products and companies will produce them. 
For product liability law to serve a constructive role from the standpoint of setting the efficient level of product risk, there must be some form of market failure, such as inadequate consumer knowledge of the risks. The presence of product-related injuries is not sufficient for concluding that there is an inadequate level of safety. In a typical personal injury case with an identifiable victim, the probability of harm may appear to be 1.0 ex post since the consumer was in fact injured, but what matters is the level of the risk ex ante across the entire population of consumers of the product. In judging whether there is a shortcoming in risk beliefs, the task is to ascertain what a reasonable consumer would have anticipated as the probability of harm, not whether the injured consumer was clairvoyant and anticipated that there would definitely be an injury.

Whether risk beliefs are accurate depends both on the level of the risk and the degree to which people have information about the risk. Certainly it is rarely the case that people know the exact probabilities of harm from different products. Products often pose multiple risks, and understanding all these hazards may require detailed technical expertise. However, the appropriate task for consumers is to have a sufficient understanding of the multiple risks of the product so that they would assess the expected cost imposed by the harms as being as severe as they would in a situation of perfect information.

That consumers do not have perfect risk beliefs does not necessarily imply that there is a market failure. Errors in risk beliefs are not random. Many systematic patterns have been identified in the empirical literature on risk beliefs. A pertinent empirical phenomenon is that people tend to overestimate small mortality risks, such as the risk of dying from botulism, and underestimate very large risks, such as the lifetime risk of heart disease from all causes. For the most part, product risks tend to involve small probabilities of serious adverse outcomes, and consequently people will exhibit a tendency toward risk overestimation of product-related risks.

Problems of risk underestimation will be more pronounced for hidden risks. The presence of benzene in Perrier that was discovered in 1990 is a well-known example of a risk that had formerly been hidden, but this is not a unique situation. Medical patients may not be aware of adverse drug interactions that are not disclosed to the patient and cannot be determined by the patient based on personal experience or other information sources. The locus of areas in which government regulation or product liability can play a constructive role will depend on the nature of the risk and what consumers know about the risk. In particular, if there is asymmetric information in which the manufacturer is informed but consumers are not, then government regulation-such as required disclosure of information-may be warranted.

\section{Liability Criteria}

The first question is when liability should be imposed, and this will depend on the context of the product's use. For concreteness, I will concentrate on products purchased by a consumer in a market context, where the potential injury is to the consumer. Whether consumers understand the risk to themselves is a pivotal concern. Consumers will be willing to pay less for products that may cause them harm. Products may also injure third parties who are not involved in a business relationship with the producer. Thus defective brakes or acceleration problems with a car could lead to harm to pedestrians or other drivers' vehicles. To the extent that these harms are subsequently internalized by the product purchaser through tort liability, the consumer in turn will incorporate the cost of such harms in the purchase decision. There can, of course, be exceptional cases that are not adequately addressed either by the market or tort liability, as when firms scale back tort liability claims through bankruptcy proceedings.

The structure of standard liability rules can potentially lead to efficient levels of safety. Under a negligence standard, firms will only be liable for product-related injury costs if the level of safety that they provide is below the legal standard. If that standard is set at the economically efficient level of safety for the product, the failure to meet the standard will lead firms to pay injured parties for the cost of the accident, leading the firm to internalize these costs, which in turn will provide subsequent incentives for the firm to provide products with levels of safety that meet the standard.

The economic analysis for strict liability is simpler as there is no need to set the standard at an efficient level. Since firms will pay for all accident costs, the firm internalizes all safety losses associated with the product and consequently will provide an efficient level of safety. However, consumers will not have any incentive to exercise care, to choose safe products, or to match their product choices with their own safety-related productivity if all accident costs are borne by the firm. Standard law and economics prescriptions generally couple strict liability with a contributory negligence standard.

\section{Liability and Risk Trends}

The rise of product liability costs and, in particular, the emergence of occasional product liability "crises" would be consistent with an underlying soundly functioning liability regime if an increase in product risks accounted for the high liability costs. However, by almost every measure the United States has become safer over the past century and accident rate trends bear no apparent relation to surges in liability costs. Total unintentional injury death rates have declined for over a century. Data going back almost a century are available for individual component risks such as work-related deaths, home-related deaths, accidental deaths from firearms, and other risks, and these hazards also have declined from their levels 80 years ago. The principal exception is that the number of motor-vehicle deaths and motor-vehicle death rates are higher than they were a century ago. However, the number of cars in use and the usage of these cars have risen dramatically over time. Adjusting for intensity of use, motor-vehicle risks have plummeted 
from 33.38 deaths per 10,000 vehicles in 1913 to 1.51 deaths per 10,000 vehicles in 2008. Similarly, the death rate per 100 million miles has decreased from 21.65 in 1923 to 1.33 in 2008.

Despite the high levels of safety and continued improvements in safety, product-related insurance costs remain high. The value of net premiums in 2008 was $\$ 1.3$ billion for aircraft liability, $\$ 2.8$ billion for product liability and $\$ 38.6$ billion for other liability including industry coverages for negligence, carelessness, or failure to act. Many large firms also self-insure so that examination of insurance premiums alone understates the cost of product liability to firms throughout the economy.

Longer-term trends in liability reflect factors other than safety levels alone. As society has become wealthier, we have become less willing to accept risk. Advances in technology also can increase liability levels if the standards for what constitutes reasonable care have changed.

These long-run trends do not, however, account for very abrupt shifts in the level of liability. A puzzle noted by law professor George Priest is that, within specific time periods in which product liability premiums have exhibited sharp increases, there is no apparent increase in product risk levels to account for the increase. There is therefore a mismatch between the surges in liability costs associated with the tort liability crisis in the mid1980s and the level of product-related risks. The periodic upward shifts in liability costs bear no apparent relation to increased levels of product riskiness.

The problems posed by product liability insurance are related both to the level of liability insurance costs and their variability, which creates substantial uncertainty for the firm. The absence of predictable liability costs will make it difficult for firms to distinguish which safety investments are worthwhile and which are not. This problem is much more acute for bodily injury losses than property losses. The main index of insurer profitability is the loss ratio, which is the ratio of losses to premiums. Ignoring the role of interest earned on premiums that are invested, a loss ratio above 1.0 implies that the insurer is losing money, and a loss ratio below 1.0 implies that the insurer is making money on the policies it has written. Thus the loss ratio is an inverse measure of insurer profitability. The bodily injury component of liability exhibited much higher loss ratios and more variable loss ratios than did the property damages component throughout the liability crisis period.

In a competitive market that has reached long-run equilibrium, one would expect insurer profitability as measured by the insurance loss ratios to be equalized across industries and for different kinds of insurance coverage-assuming other reasonable conditions are met, including a similar distribution over time in the occurrence of the losses. However, there is evidence of substantial variation in terms of the level of the loss ratios as well as the variability across industries and within industries.
The profitability problems of insurance are more pronounced for bodily injury coverage, as is the variability in loss ratios, which in turn will create more highly variable premiums and uncertainty for the affected industries.

The high loss ratios and substantial variability of loss ratios for bodily injury coverage in the 1980s contributed to the tort liability crisis of that era. Insurers responded by raising insurance rates and, in some extreme instances, denying coverage. In addition, to the extent that the fluctuation in insured losses reflects loss trends more generally, the uninsured costs will exhibit similar fluctuations.

After the passage of a series of tort liability reforms in the mid1980s to contain damage awards, insurance loss ratios stabilized. For general liability, there were widespread reform efforts as 12 states enacted reforms to control liability costs in 1985, 22 states enacted reforms in 1986, and 12 states enacted reforms in 1987. Whereas general liability loss ratios formerly had exceeded 1.0, in 1986 and subsequent years loss ratios decreased to levels that stabilized around 0.8 .

The costs of liability imposed on insurers are but one manifestation of the costs borne by firms. To assess the liability costs for firms, Joni Hersch and I undertook a stock market event study of 29 product liability lawsuits. Such studies seek to determine statistically the effect of different events, such as major court decisions, on a firm's stock price after taking into account longerrun trends and other factors. The awards against companies were associated with a significant decline in stock market price relative to similar firms. It is also noteworthy that newspaper reports of pending lawsuits also led to negative returns as investors began to anticipate the adverse effects of product liability.

\section{Innovation and New Product Development}

The costs imposed by product liability law might serve a useful deterrence function if they provide incentives for firms to change their products to make them safer or for firms to discontinue products that are so unsafe that they should not be marketed. These effects flow from the basic economic theory and the structure of product liability law. However, the presence of substantial uncertainty in liability costs will tend to mute these effects, and there is no assurance that jury decisions will provide the right signals to firms.

Determining whether and how product liability affects product design are empirical issues, and the results are not encouraging. A useful proxy for assessing whether product liability law 
enhances product safety is to see if it stimulates the development of new, possibly safer products. There have been two regression analysis studies at the firm level of the overall relationship between product liability and product innovation, neither of which found effects that supported the textbook paradigm of higher liability costs fostering the introduction of safer products. Similarly, there has been one regression analysis study of decreases in the role of product liability and it showed that such changes did not undermine safety but instead may have had the opposite effect.

Novel risks have been found to be harder hit by liability costs than more familiar hazards. Michael J. Moore and I examined the effect of product characteristics on liability costs as well as the effect of liability costs on research and development. Industries that have a high rate of technological change or that have a high patent rate have high shares of liability costs relative to sales for the firm. In contrast, industries where the firms have made no new product introductions have lower bodily injury liability costs. These relationships are consistent with the view that the courts dislike novel technologies.

The study also found that increased product liability has a nonlinear effect on innovation. Low levels of liability boost investments in novel technologies, but this effect tapers off and eventually becomes reversed and turns negative at very high levels of bodily injury costs relative to sales. Thus, at very high levels of liability costs, product liability has a counterproductive effect.

A subsequent study by the same authors, using a different measure of effects on innovation, found that liability costs initially boost product research and development but then subsequently decrease $\mathrm{R} \& \mathrm{D}$ at very high levels of liability costs. The liability costs/sales variable is associated with higher product $R \& D$ investments at low levels of costs, but it eventually becomes reversed for high liability costs. Sorting out causality remains difficult, but the evidence is suggestive of a positive relation between liability costs and safety that holds only for low levels of costs.

These results suggest that product liability's aversion to new technologies has been harmful. At substantial levels of liability costs, the net effect of liability is to shut down innovation and discourage new product introductions. This is not the case at low and moderate levels of liability costs, where product liability promotes R\&D for new products and leads to new product introductions. However, even here new product introductions may not be warranted on benefit-cost grounds. This is because it is not clear whether consumers would be willing to pay the extra cost for the safety improvements. We lack data to permit such judgments on an overall basis. What we do know is that extremely high liability costs appear to have counterproductive effects as they impose substantial costs but discourage changes in products and new product research. Withdrawing products from the market or choosing not to introduce new products often becomes the most desirable course in the presence of substantial expected liability costs.

New safety technologies should of course be encouraged, and these results are therefore troubling. If product liability was meant to reduce risk, it seems to have failed in its mission. Strikingly, one study found that reducing tort liability makes us safer. An empirical analysis by Paul Rubin and Joanna Shepherd found that the enactment of noneconomic damages caps and product liability reform were among the measures associated with a decrease in the non-motor vehicle accidental death rate over the 1981-2000 period for states that implemented those measures as compared to states that did not. On balance, tort reform led to a reduction of 24,000 deaths over the two-decade period. Reductions in liability costs enhance safety.

\section{Punitive Damages}

Punitive damages often combine two elements that tend to reduce the efficacy of product liability as a safety incentive promotion device. The awards often tend to be very large. As we saw, very large damages amounts tend to have a counterproductive effect in that they serve to reduce $R \& D$ on new products, diminish new product introductions, and lead to withdrawal of more novel or risky products from the market. The second difficulty with punitive damages is their tremendous uncertainty and unpredictability. If firms cannot anticipate what financial sanctions they will incur for various product designs, there will not be the clearcut incentive guidance needed to foster efficient risk levels.

The enormous scale and financial uncertainty associated with punitive damages is borne out in "blockbuster punitive damages awards," or punitive damages awards of at least $\$ 100$ million. As of 2008 there had been 100 such awards that reached or exceeded the $\$ 100$ million threshold. Even within the blockbuster punitive damages award grouping, there is tremendous variability in the award amounts, which reach as high as $\$ 145$ billion in Engle v. R.J. Reynolds, a cigarette class action case in Florida.

These awards do not reflect any sense of what is appropriate from the standpoint of establishing efficient levels of safety. Although law-and-economics models generally envision a deterrence role for punitive damages only in cases with a probability of detection below 1.0 (where compensatory damages might not adequately deter because some harms are undetected), punitive awards bear little relation to any meaningful principles for establishing safety incentives. To the extent that the awards are designed by jurors to punish the company or "send it a message," there will be associated fixed costs incurred by the company, but these awards tend not to impose the kinds of costs that can be reflected in the expected costs of production and hence will not serve as a safety incentive mechanism.

Table 1 provides a breakdown of the distribution of the blockbuster punitive damages awards. With the exception of seven awards for violent crimes, the defendant in these blockbuster cases is a firm in one of the designated industry groups. Most of the industry cases are product-related. There are, of course, some notable exceptions, such as awards for fraud against the finance, investment, and insurance industry group, and the award for the Exxon Valdez oil spill that affects the energy and chemical 
industry tally. However, most of the industry group awards can be traced to product-related risks.

The automobile, cigarette, and pharmaceutical awards all involve products. While one automobile case (BMW of North America Inc. v. Gore) involved the repainting of car doors, the other cases involved deaths and serious injuries associated with motor vehicles. Because these cases tended to involve claims of design defects for which the risks were not apparent at the time of sale, the liability costs associated with these punitive damages could not be internalized. Moreover, there is no reason to believe that firms would anticipate punitive damages awards in excess of $\$ 100$ million.

The five blockbuster awards against the cigarette industry that are shown in Table 1 are all for individual smoker harms. The class action case in the outlier Engle award is the sixth blockbuster case affecting the cigarette industry, and is not included in Table 1 since it is such a large award that it would distort the mean award levels. Because there is a latency period of decades before smoking risks become apparent, the cigarettes involved in these cases were marketed long before there were any such blockbuster punitive damages awards, as the first such blockbuster punitive damages award in any context was in 1985 . Moreover, since the cigarette industry had never paid damages in any smoking case until after the 1998 Master Settlement Agreement, firms would not have incorporated the subsequent liability costs into the product price at the time of sale since the costs presumably were not anticipated at the time of sale. Thus, from the standpoint of safety incentives, there is a mismatch between the imposition of the blockbuster punitive damages awards and the formation of corporate expectations and product safety decisions that could ultimately affect the likelihood and level of such awards.

The tremendous uncertainty posed by large and unpredict-

\section{TABLE}

\section{Damage Awards}

Blockbuster punitive damages and the ratio of punitive damages to compensatory damages by industry type.

\begin{tabular}{|c|c|c|c|c|}
\hline INDUSTRY INVOLVED & $\begin{array}{l}\text { NUMBER OF } \\
\text { PUNITIVE } \\
\text { DAMAGES } \\
\text { AWARDS }\end{array}$ & $\begin{array}{l}\text { MEAN PUNITIVE } \\
\text { DAMAGES } \\
\text { (Millions of } \\
\$ 2008 \text { ) }\end{array}$ & $\begin{array}{l}\text { MEAN } \\
\text { COMPENSATORY } \\
\text { DAMAGES } \\
\text { (Millions of } \\
\$ 2008)\end{array}$ & $\begin{array}{l}\text { MEAN RATIO OF } \\
\text { PUNITIVETO } \\
\text { COMPENSATORY } \\
\text { DAMAGES }\end{array}$ \\
\hline Automobile & 9 & 900.71 & 160.89 & 19.12 \\
\hline Cigarette $^{1}$ & 5 & $10,240.92$ & $2,078.87$ & $11,125.31$ \\
\hline Energy, Chemical & 25 & $1,531.59$ & 701.61 & 90.09 \\
\hline $\begin{array}{l}\text { Finance, Invest- } \\
\text { ment, Insurance }\end{array}$ & 23 & 546.33 & 222.45 & 59.20 \\
\hline $\begin{array}{l}\text { Pharmaceuticals, } \\
\text { Health Care }\end{array}$ & 16 & 503.69 & 109.29 & 40.98 \\
\hline Violent Crime & 7 & 350.05 & 114.49 & 19.87 \\
\hline Other & 15 & 273.63 & 103.00 & 13.82 \\
\hline \multicolumn{5}{|c|}{$\begin{array}{l}\text { 'All columns exclude the Engle award. } \\
{ }^{2} \text { The mean ratio excludes Garamendi v. Altus Finance S.A., which has zero compensatory damages. } \\
\text { Source: “The Changing Landscape of Blockbuster Punitive Damages Awards," by Alison F. Del Rossi and W. Kip Viscusi. } \\
\text { American Law and Economics Review, Vol. } 12 \text { (2010), Table 2. }\end{array}$} \\
\hline
\end{tabular}

able punitive damages awards has attracted the attention of the U.S. Supreme Court. The Court's decision in State Farm v. Campbell suggested that there be a single-digit upper bound on the ratio of punitive damages to compensatory damages, and for maritime cases the Court subsequently suggested a usual upper bound ratio of 1:1 in Exxon Shipping Co. et al. v. Baker. These guidelines are not necessarily binding and they do not serve to put punitive damages on fully rational footing. As with all such soft or binding caps, the proposal that there be some kind of rigid mathematical structure that is not informed by a sound basis for setting punitive damages does not address the more fundamental problem that juries do not have guidelines for mapping their concerns into dollar damages amounts.

A series of experimental studies by Cass Sunstein et al. has documented numerous shortcomings in jury behavior, some of which will be discussed below with respect to specific problems that arise with respect to product liability cases. But the fundamental problem is that juries are being asked to determine whether punitive damages are warranted and, if so, to set the magnitude of these awards without any specific guidance as to how their assessment of the defendant's behavior should relate to the dollar value of the award.

As with product liability generally, whether punitive damages do have a deterrent effect ultimately is an empirical question. In an examination of differences in risk levels between states that permit punitive damages awards and those that do not, I found no evidence of such a deterrent influence. The risk categories examined included toxic chemical accidents, toxic chemical accidents involving injury or death, toxic chemical releases, surface water discharges of chemicals, total chemical releases in surface water, medical misadventure deaths, total accidental deaths, total insurance premiums, medical malpractice insurance premiums, product liability premiums, and other liability premiums. The examination of an extensive set of risks that potentially could be influenced by punitive damages reveals no statistically significant deterrent effect.

\section{Uncertainty, Hindsight Bias, and New Products}

As we saw, product liability costs are particularly likely to affect new products and to discourage new product introductions when liability costs are high. This differential burden on new products can be traced to a series of contributing factors in terms of how people perceive uncertain risks, such as the hazards posed by new products, as compared to comparable risks from existing products for which the risks are better known.

One source of bias can be traced to 
ambiguity aversion. In the classic Ellsberg paradox, people would prefer a known probability of winning a prize to an uncertain probability of the same magnitude. Subsequent work has shown that in the case of people facing losses, precisely understood probabilities of the loss are viewed as less harmful than less well understood probabilities of the same magnitude. While there are some exceptions to this pattern, particularly when probabilities are extremely close to zero or one, there is a well-established aversion to facing imprecisely understood chances of a loss.

How this bias affects judgments is illustrated by experimental results I obtained for a sample of state court judges. The judges were asked, on behalf of a pharmaceutical company, to decide between two different drugs that could be used as contrast agents in a CAT scan. "Old Drug" had well-known properties have nothing to gain from maiming their customers and employees, willingly pay for cost-effective precautions.... Come the lawsuit, however, the passenger injured by a stop presents himself as a person, not a probability. Jurors see today's injury; persons who would be injured if buttons were harder to find and use are invisible. Although witnesses may talk about them, they are spectral figures, insubstantial compared to the injured plaintiff, who appears in the flesh.

Unfortunately, despite the well-established problems associated with hindsight bias, it is difficult for people to overcome such biases when judging risky behaviors. To test the influence of hindsight bias, I examined the performance of judges and jurors in a rail accident case in which different groups of respondents were asked either to make the corporate risk-taking decision ex ante or to judge the corporation's decision after an accident had occurred. Judges performed better than jurors in terms of aligning their ex ante risk decisions and their judgments after an accident had occurred. However, in the jury sample, participants favored and offered a 1:100,000 chance that the patient would suffer a fatal adverse reaction. "New Drug" served the same function, and based on clinical trials the best estimate of the expected magnitude of the risk was 1:150,000. However, the risk posed by New Drug was uncertain, as it could have been zero or as high as 1:50,000. Even though New Drug was safer based on the expected level of risk, 57 percent of the respondents preferred to market Old Drug. In discussions with the judges regarding their preference for the riskier but well known hazards of Old Drug, the judges indicated that there is less blame accorded to companies that market risky products with well-known hazards than for newly emerging risks.

Another perceptional factor that influences people's assessments of new products with uncertain properties is hindsight bias, which is the courtroom counterpart of Monday morning quarterbacking. Product liability claims, by their very nature, are filed after there has been an injury. At the time the product is marketed, the risk may be an uncertain prospect, but eventually the hazard becomes well known. Ideally, jurors should assess risks at the time the product is marketed. However, doing so is difficult from a psychological standpoint. Once the adverse event occurs, people tend to believe that the risk should have been anticipated.

The tendency of people to overestimate the ex ante risk levels in legal contexts where there are identifiable victims was noted by Judge Frank Easterbrook in Carroll v. Otis Elevator, a case involving injury on a department store escalator:

The ex post perspective of litigation exerts a hydraulic force that distorts judgment. Engineers design escalators to minimize the sum of construction, operation, and injury costs. Department stores, which the risk-taking behavior before the accident occurred, but after an accident occurred levied punitive damages because the initial decision to take the risk was regarded as reckless.

\section{Corporate Risk Analysis for Risky Products}

Ideally, companies marketing potentially risky products should make some assessment of the risk posed by the product, the costs associated with improving product safety, and consumers' likely valuations of products with different levels of safety to determine the efficient safety level for the product. At the most formal level, such an assessment would entail a benefit-cost analysis to determine the appropriate level of the risk.

While such assessments may be desirable in theory, in practice they make the company very vulnerable. Having done a risk analysis and concluded that some risk-free or lower-risk variant of the product is not desirable, the company will appear to have knowingly made a reckless decision to expose consumers to risk if it turns out that there are product-related injuries. Thus such analyses could serve as a trigger for the award of punitive damages instead of being treated as a component of responsible corporate risk decisions.

Such fears of harsh judgments against corporate risk analyses have been borne out in a variety of major product liability cases. The Ford Pinto cases involved drivers and passengers who suffered burn injuries while in the car. In response to a government regulatory initiative from the U.S. Department of Transportation, Ford had done a risk analysis with respect to moving the gas tank location, which would have affected the likelihood of burn injuries. Moving the tank to a safer location would have raised the product price and Ford concluded the change would 
not pass a benefit-cost test. After the injuries occurred, jurors tended to compare the identifiable victims with the minor cost of relocating the tank, whereas the more appropriate comparison would have been the expected benefits and costs before the product was marketed.

Ford is not the only automobile company that has been pilloried for undertaking corporate risk analyses. In a blockbuster punitive damages award case against the Chrysler Corporation, jurors awarded punitive damages of $\$ 250$ million because the company had done a risk analysis of an allegedly defective door latch in the Chrysler minivan. Chrysler maintained that the door latch did not increase the risk significantly and that altering the design was not worthwhile as it would have imposed a $\$ 100,000$ fixed retooling cost and a $\$ 0.50$ per vehicle parts cost. The plaintiff's attorneys portrayed Chrysler as a corporate villain simply for undertaking a risk analysis: "Chrysler officials at the highest level cold-bloodedly calculated that acknowledging the problem and fixing it would be more expensive, in terms of bad publicity and lost sales, than concealing the defect and litigating the wrongful death suits that inevitably would result."

Experimental evidence indicates that undertaking a benefitcost analysis increases judgments against the corporation. In this study, jurors were told that the company followed the same procedures used by the National Highway Traffic Safety Administration in assessing safety devices and that the company also used the same value of statistical life (VSL) that the agency uses to value the safety improvements of alternative designs. The VSL amount is greater than the usual compensatory damages award for wrongful death, and so one would expect a finding of no liability. However, the mock juries levied punitive damages against the company. Thus responsible corporate risk analysis has the perverse effect of boosting damages awards rather than reducing them.

\section{Conclusion}

Rather than creating an environment to foster safer products, product liability law often has adverse consequences. Some of the problems stem from the inherent nature of product risk decisions and the function of tort liability, while others may derive from individuals' cognitive limitations and inability to think properly about balancing risk and cost. Thus it would be both incorrect and an oversimplification to blame all the ills on the tort liability system. That system functions reasonably well for many types of accidents, such as personal motor vehicle accidents. However, tort liability falls short with respect to products.

The first class of problems stems from the judgment biases of jurors. Because of loss aversion biases, jurors will impose excessive penalties on novel risks. Because of hindsight biases, jurors will believe incorrectly that the risk could have been anticipated.

The second class of problems arises from excessive levels of damages. Although jurors tend to agree about what behavior is blameworthy, they are all over the map in assessing damages. Compensatory damages for economic loss are reasonably well defined. However, assessments of pain and suffering awards and punitive damages awards are fraught with error, no doubt in part because jurors are not given firm guidance with respect to how they should go about setting the level of these damages. The result is that there may be multi-billion-dollar blockbuster punitive damages awards, but these awards do not enhance safety because they are random, rare events. More generally, for large levels of punitive damages costs, there is in fact a counterproductive effect of punitive damages that discourages product improvements and new product introductions. Exiting the market altogether is often the desired course.

Third, firms are hampered in their efforts to reduce risks in an efficient manner by juror aversion to the measurement of risk. Companies that conduct risk analyses are vilified for intentionally endangering the public. When confronted with particular injury cases, the jury's balancing abstracts from the ex ante expectations that necessarily guide corporate decisions and instead compare the identifiable victim with the product-specific cost of greater safety.

\section{READINGS}

" "An Industrial Profile of the Links between Product Liability and Innovation," by W. Kip Viscusi and Michael J. Moore. In The Liability Maze: The Impact of Liability Law on Safety and Innovation, edited by Peter W. Huber and Robert E. Litan; Brookings Institution Press, 1991.

घ "Corporate Risk Analysis: A Reckless Act?” by W. Kip Viscusi. Stanford Law Review, Vol. 52 (2000).

- Foundations of Economic Analysis of Law, by Steven Shavell. Harvard University Press, 2004.

- "How Do Judges Think about Risk?” by W. Kip Viscusi. American Law and Economics Review, Vol. 1 (1999).

n- "Product Liability Law and the Accident Rate," by George Priest. In Liability: Perspectives and Policy, edited by Robert E. Litan and Clifford Winston; Brookings Institution Press, 1988.

- "Product Liability, Research and Development, and Innovation," by W. Kip Viscusi and Michael J. Moore. Journal of Political Economy, Vol. 101 (1993).

- Punitive Damages: How Juries Decide, by Cass R. Sunstein, Reid Hastie, John W. Payne, David A. Schkade, and W. Kip Viscusi. University of Chicago Press, 2002.

- Reforming Products Liability, by W. Kip Viscusi. Harvard University Press, 1991.

n- "The Dimensions of the Product Liability Crisis," by W. Kip Viscusi. Journal of Legal Studies, Vol. 20 (1991).
- "The Market Response to Product Safety Litigation," by W. Kip Viscusi and Joni Hersch. Journal of Regulatory Economics, Vol. 2 (1990).

- "The Myth of the Ford Pinto Case," by Gary T. Schwartz. Rutgers Law Review, Vol. 43 (1991).

- "The National Implications of Liability Reforms for General Liability and Medical Malpractice Insurance," by W. Kip Viscusi and Patricia Born. Seton Hall Law Review, Vol. 24 (1994).

n- "The Social Costs of Punitive Damages against Corporations in Environmental and Safety Torts," by W. Kip Viscusi. Georgetown Law Journal, Vol. 87 (1998).

- "Tort Reform and Accidental Deaths," by Paul H. Rubin and Joanna M. Shepherd. Journal of Law and Economics, Vol. 50 (2007). 
Copyright of Regulation is the property of Cato Institute and its content may not be copied or emailed to multiple sites or posted to a listserv without the copyright holder's express written permission. However, users may print, download, or email articles for individual use. 